\title{
口腔原発扁平上皮癌における $\mathbf{E}-$-カドヘリン発現と浸潤様式との関連
}

\author{
楿 敏 男・和唐雅博*・田中昭男*・梶隆一
}

植野茂・覚道健治・虫本浩三・白数力也

\section{Relationship between the expression of $\mathbf{E}$-cadherin and the mode of invasion in human primary oral cancer}

\author{
Toshio Sakaki • Masahiro Wato* - Akio Tanaka* \\ Ryuichi Kaji $\cdot$ Shigeru Ueno $\cdot$ Kenji KakUdo \\ Kozo Mushimoto • Rikiya Shirasu
}

\begin{abstract}
We carried out immunohistochemical investigations on the relationship between the expression of E-cadherin and the clinical stage and mode of invasion of human primary oral cancers (squamous cell carcinomas).

We found that cancers having a grade 4 mode of invasion displayed a reduced type of E-cadherin expression by the classification of Shiozaki et al.

This suggests that decreased expression of E-cadherin is closely related to the high invasiveness of cancer cells.
\end{abstract}

Key words: E-cadherin (E-カドヘリン), oral squamous cell carcinoma (口腔扁平上皮癌), immunohistochemistry (免疫組織化学), invasiveness (浸潤能)

緒

言

カドヘリンは, カルシウムに化存した細胞間接着に関 与する膜買通性の糖蛋白である ${ }^{1)}$ 。この接着分子には, $\mathrm{E}$ (上皮) 型, $\mathrm{P}$ (胎盤) 型, $\mathrm{N}$ (神経) 型, $\mathrm{V}$ (血管) 型などのホモフィリックな結合特異性をもつサブクラス があり ${ }^{2,3)}$, 各分子は胚発生や器官形成の 各段階で時間 的・空間的に铰密に規制されダイナミックに発現するこ とが知られている ${ }^{4,5)}$. 上皮細胞間の接着には $\mathrm{E}-$ カドへ リンが選択的に作用して組織の構築に関与する.

一般に正常組織では, 細胞同士の強固な接着によって 組織の構築と機能が維持されている。 それに対して, 癌

大阪詸科大学:口腔外科学第 1 讙座

(主任: 白数力也教授)

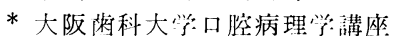

(主任：由中昭男教授)

First Department of Oral and Maxillofacial Surgery, Osaka Dental University (Chief: Prof. Rikiya Shirasu)

* Department of Oral Pathology, Osaka Dental University (Chief: Prof. Akio Tanaka)

受付日：平成 5 作: 2 月 9 日
組織に扣いては浸潤・転移といら異常な細胞の行動がみ られ, これらの最初のステップは癌細胞の集団からの脱 離によって始まる。

そこで, 本研究では臨床的進行度の異なる10症例の口 腔原発扁平上皮癌の一次症例を対象に細胞間の接着に関

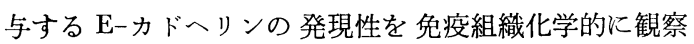
し, 癌の臨床的進行度および病理組織学的浸潤様式と E-カドヘリン発現様式との関連について検討を加えた。

\section{材料および方法}

1990年 3 月から1992年10月までの 2 年 7 か月間に

大学附属病院第 1 口腔外科を受診した10例の口腔原 発扁平上皮癌患者の一次症例から得た生検組織を対象と した。各癌の臨床的進行度は, UICC 提案(1987年度)の 病期分類 ${ }^{6}$ に従って区分し, 組織学的分類には WHO の 分類7)を用いた。 また, 癌の浸潤様式は Yamamoto ら ${ }^{8)}$ の分類に, E-カドヘリンの発現様式（強度と均一性）は Shiozaki ら99の分類にそれぞれ従って区分した。

免疫組織化学的観察に扣いては, 採取した生検組織の

一部をただちに OCT compound (Miles Scientific,

IL, USA) 飞包埋後, $-80^{\circ} \mathrm{C}$ で凍結して未固定の $6 \mu \mathrm{m}$ 凍結切片とした。切片は冷アセトンで $4^{\circ} \mathrm{C}, 5$ 分間固定 
表 $\mathrm{E}$-カドヘリンの発現様式と口腔原発癌の臨床的進行度および浸潤様式

\begin{tabular}{|c|c|c|c|c|c|c|c|}
\hline 症例 & 性別 & 年齢 & 部位 & TNM 分類 & 病期分類 & 浸潤様式 & $\mathrm{E}-カ ト ゙ ヘ リ ン$ 発現様式 \\
\hline 1 & $\mathrm{~F}$ & 63 & 歯肉 & T3N0M0 & III & 2 & Pr \\
\hline 2 & $\mathrm{~F}$ & 59 & 歯肉 & T1N0M0 & I & 3 & $\operatorname{Pr}$ \\
\hline 3 & $\mathbf{M}$ & 49 & 舌 & $\mathrm{T} 4 \mathrm{~N} 2 \mathrm{M} 0$ & IV & $4 \mathrm{D}$ & $\operatorname{Re}$ \\
\hline 4 & $\mathrm{~F}$ & 84 & 舌 & T3N1M0 & III & $4 \mathrm{C}$ & $\mathrm{Re}$ \\
\hline 5 & $\mathbf{M}$ & 71 & 歯肉 & T2NOM0 & II & 2 & $\operatorname{Pr}$ \\
\hline 6 & $\mathrm{~F}$ & 48 & 舌 & T2N0M0 & II & $4 \mathrm{C}$ & $\operatorname{Re}$ \\
\hline 7 & M & 66 & 歯肉 & $\mathrm{T} 4 \mathrm{~N} 2 \mathrm{M} 0$ & IV & 3 & $\operatorname{Pr}$ \\
\hline 8 & M & 66 & 歯肉 & $\mathrm{T} 4 \mathrm{~N} 2 \mathrm{M} 0$ & IV & $4 \mathrm{C}$ & $\operatorname{Re}$ \\
\hline 9 & $\mathrm{~F}$ & 45 & 舌 & T2N0M0 & II & 2 & $\operatorname{Pr}$ \\
\hline 10 & F & 42 & 舌 & T1N0M0 & I & 3 & $\mathrm{Re}$ \\
\hline
\end{tabular}

Pr: Preserved type Re: Reduced type

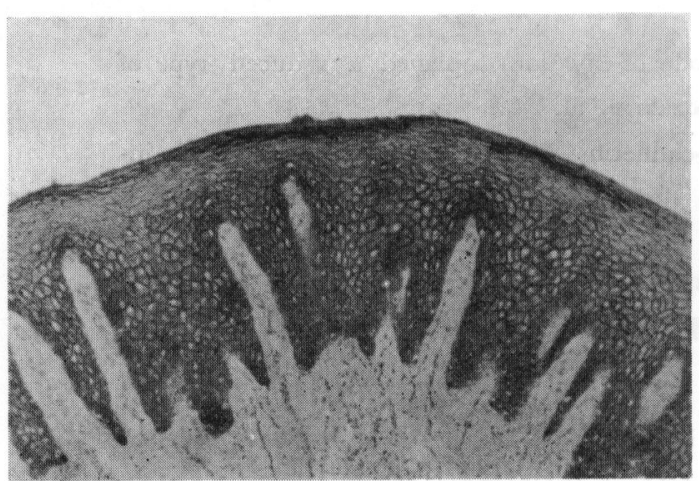

写真 1 健常歯肉に拈ける $\mathbf{E}$ 一カドヘリンの発現 $(\times 33)$.

後, $0.3 \% \mathrm{H}_{2} \mathrm{O}_{2}$ 含有メタノールに $-20^{\circ} \mathrm{C}$ で 30 分間浸 漬し, 非特異反応を抑えるために正常ヤギ血清 (Vector Lab. Inc., Burlingame, CA, USA）と室温で10分間反 応させた。 その後, 切片は一次抗体の抗ヒト $\mathrm{E}$-カドへ リンマウスモノクローナル抗体 (HECD-1, マウス IgG：京都大学 竹市雅俊教授供与) と室温で 1 時間反応 させたのち, Labelled streptavidin biotin (LSAB) 法 で免疫染色を行った。すなわち, すず二次抗体のビオチ ン化マウス IgGヤギ血清 (ICN Biomedicals Inc., Costa Mesa, CA, USA) と, ついでペルオキシダーゼ 標識ストレプトアビジン (ICN Biomedicals Inc.) とそ れぞれ室温で 10 分間反応させた。 反応終了後, 切片は $\mathrm{H}_{2} \mathrm{O}_{2}$ 添加の 3,3 -ジアミノベンチジンで発色させ, へ マトキシリンで核染色を行った. な拉, 各反応後の洗浄 には $1 \mathrm{mM} \mathrm{CaCl} 2$ を含む PBS を用いた. 対照組織に は, 歯科矯正処置 (便宜抜歯) 時に得た臨床的に健全な 歯肉粘膜組織および巨舌症患者の手術時に得た臨床的に 健全な舌粘膜組織を用いた。なお, 免疫反応の対照に

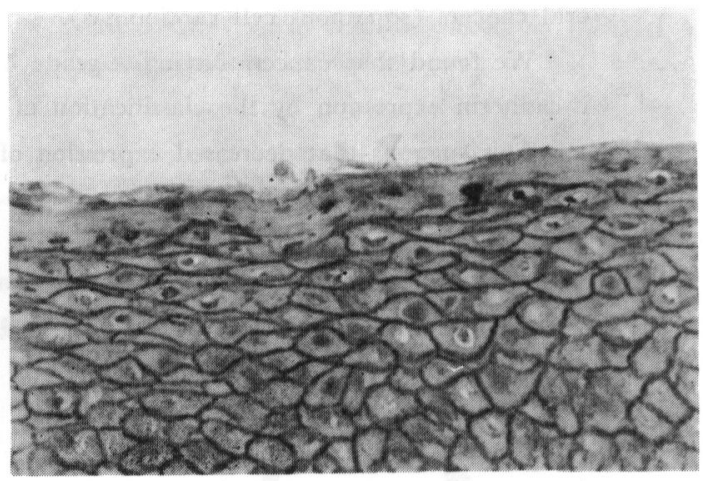

写真 $2 \mathrm{E}$-カドヘリンの発現は, 角質層の細胞膜に は認められない $(\times 132)$.

は, マウス正常血清を一次抗体として用い, 他の反応は 前記のと括りに行った。 また, 生検組織の一部をホルマ リン固定後, 通法に従いパラフィン切片とし, H-E 染色 して病理組織学的に観察した.

結果

対照組織の $\mathrm{E}$-カドヘリンに対する 反応は, 有棘細胞 層と基底細胞層（基底膜と接する部位を除く）の細胞膜 に強く発現した（写真１）。しかし，角質層の細胞膜お よび基底細胞層の基底膜に接する部位の細胞膜には発現 しなかった（写真 2,3 ）.

今回用いた10症例の口腔原発扁平上皮癌の組織型は, すべて高分化型 (Grade I) で, 病期分類では I 期が 2 例, II 期が 3 例, III 期が 2 例， IV 期が 3 例であった。 ま た, 浸潤様式では 2 型が 3 例, 3 型が 3 例, $4 \mathrm{C}$ 型が 3 例，4D型が 1 例であった（表）.

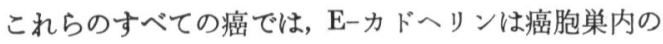




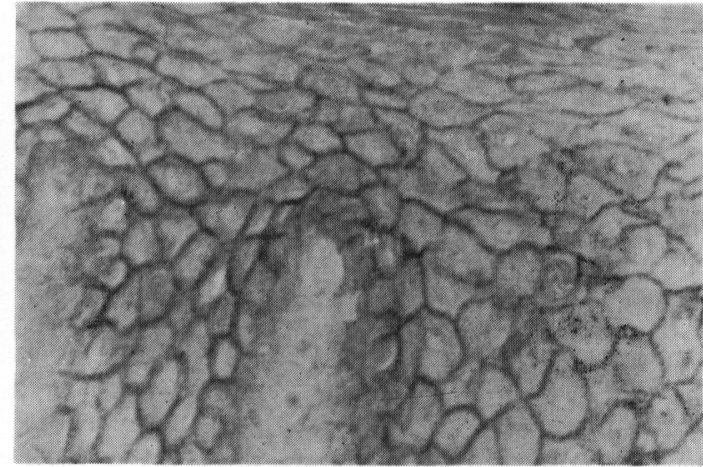

写真 $3 \mathrm{E}$-カドヘリンの発現は, 基底細胞の基底膜 に接する部位の細胞膜には認められない $(\times 132)$,

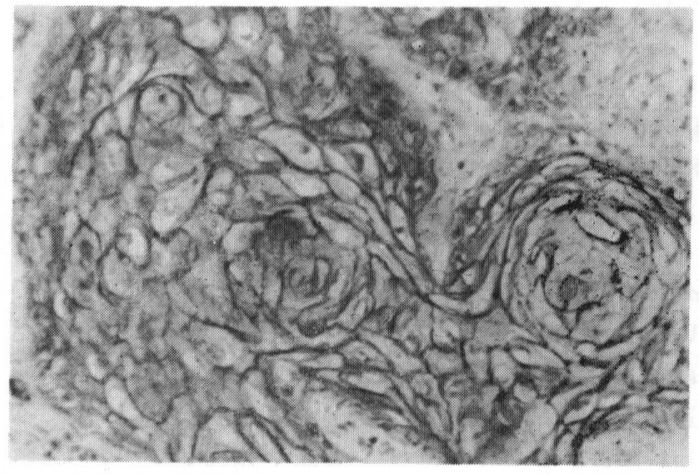

写真 4 癌組織に括ける E-カドヘリンの発現. 癌細胞の細胞膜に強く均一に発現している (preserved type) $(\times 66)$.

細胞膜に発現した（写真 4). しかし, その発現は癌胞 巣の外側に向からにしたがって減弱し, 基底膜に接する 癌細胞の細胞膜, および間質と癌真珠には発現しなかっ た、また， E-カドヘリンの発現様式は多彩で，対照組織 之同様に細胞膜に均一に強く発現しているもの（写真 4 ), 対照組織に比べて発現が減弱し, 不均一に発現し ているもの (写真 5 ), 癌胞巣全体で発現が 減弱してい るもの（写真6）などがみられた。 しかし， E-カドへリ ンの発現をまったく欠失している症例は認められなかっ た。

口腔原発扁平上皮癌の臨床的進行度と $\mathrm{E}$-カドヘリン 発現様式との関連を検討したところ, 病期分類が I 期で あっても E-カト゚ヘリン発現が弱く不均一なパターンを 示すもの (減弱型, reduced type ${ }^{9)}$ ) や, IV 期であって も $\mathrm{E}$-カドヘリンが強く均一に発現しているもの（非減 弱型, preserved type ${ }^{9)}$ ) もあり, 一定の傾向はみられな かった (表). 一方, 癌の浸潤様式と E-カドヘリン発現 様式との関連を検討すると, 著明な浸潤を示す 4 型の症

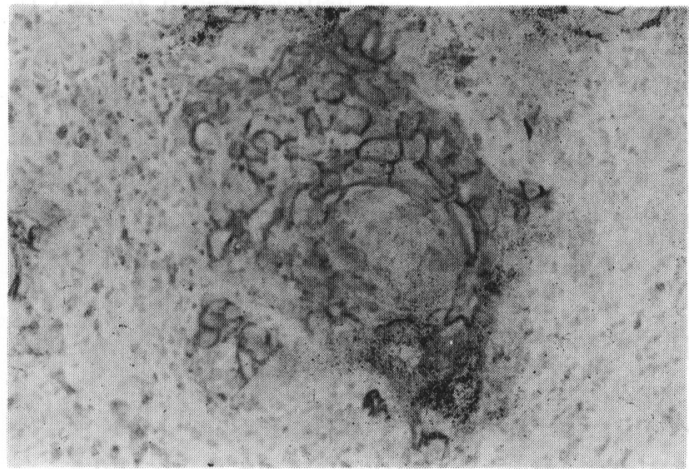

写真 5 癌組織における $\mathrm{E}$-カドヘリンの発現. 健常歯肉に比べて発現は隇弱し, 不均一に 発現している (reduced type) $(\times 66)$.

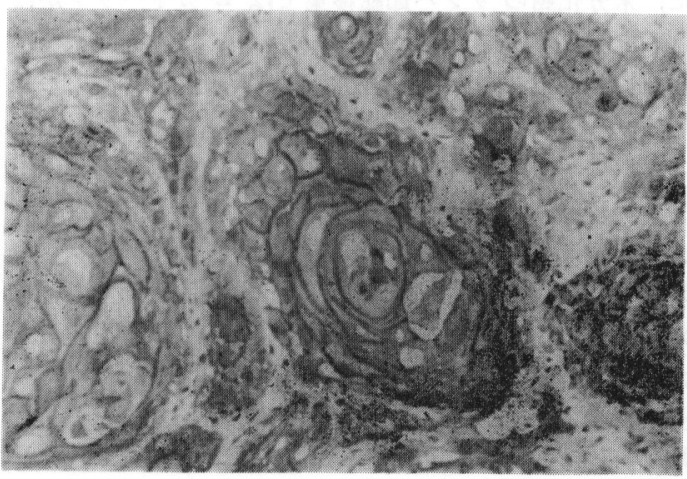

写真 6 癌組織に括ける $\mathrm{E}$-カドヘリンの発現. 癌胞栄全体で発現が減弱している (reduced type) $(\times 66)$.

例では全例カドヘリンの発現は減弱型であった。

な特, 一次抗体としてマウス正常血清を使用した対照 では, 全例反応は陰性であった。

\section{考察}

最近, 細胞一細胞間あるいは細胞一細胞外マトリック ス間の接着分子と癌の浸潤・転移との関連が分子生物学 的な研究から注目されている。 今回，わたくしたちは口 腔原発扁平上皮癌に拈ける細胞間接着分子 E-カドヘリ ンの発現性を免疫組織化学的に観察し, 臨床病理学的所 見と対比して検討を加えた。

一般に, 重層扁平上皮における上皮細胞は生理的な状 態においてもつぎつぎに老化して脱落していくが, 細胞 の脱落に伴って基底膜近くの細胞が増殖して細胞の補充 が行われる、 E-カドヘリンの発現をみても, 臨床的に健 全な歯肉と舌の角質層では発現が欠失し, 角質層の細胞 は細胞間接着能を失って生理的に剥がれやすい状態にあ 
ることを示していた，一方，基底細胞層でも基底膜と接 する部位の細胞膜では $\mathrm{E}$ ーカドヘリンを発現しなかった が，このよらなへミデスモソームを介する基質一細胞間 の接着には，基底膜に存在するインテグリン $\alpha 6 \beta 4^{10)}$ な どの分子が機能していると考えられている. Eidelman ら ${ }^{11)}$ は基底層細胞の基底膜に接する 部位には E-カドへ リンの局在は認められないことをとト皮膚で示してお り，わたくしたちも，ヒト歯肉の電顕的観察で同様の所 見を確認している ${ }^{12)}$.

一方, 今回検索した口腔原発扁平上皮癌では, E-カド ヘリンはいずれの症例にも発現したが，その発現様式は 多彩であった。これらの症例はすべて高分化型であった ため組織分化度と E-カドヘリン発現との関連は検討で きなかったが，一般的には高分化型では強く発現し，低 分化型では減弱する傾向があるとされている ${ }^{9,13 \sim 17)}$. ま

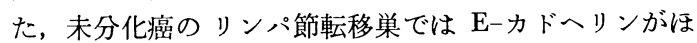
とんど発現しないことから, E-カドヘリンの発現減弱は 癌細胞の脱分化と転移に関連している可能性が高いと指 摘されている14).

本研究では, 口腔原発扁平上皮癌の病期分類とカドへ リン発現様式との間にはあきらかな相関がみられなかっ たが，浸潤様式が 4 型を示す癌では， E-カドヘリンの発 現があきらかに減弱し，かつ不均一な発現を呈する傾向 がみられた，E一カドヘリンと浸潤様式の関連を追究し

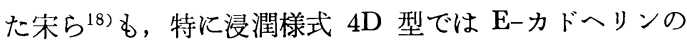
発現が減弱していることを指摘している. また最近, E-カドヘリンの cDNA をとトあるいはマウスの癌細胞 に導入してカドヘリンを強制発現させると浸潤能が阻止 され, 抗 $\mathrm{E}-$ カドヘリン抗体で処理すると再び浸潤能を 獲得することがあきらかにされ年 21)， E-カドヘリンは 癌細胞の浸潤を阻害する分子として機能することが示さ れている。また，E-カドヘリンの発現は，ヒト癌ヌード マウス移植系の増殖期に対応して減弱することも提示さ れている22).

一般に癌細胞の浸潤には, 細胞一細胞間の関連のほか に細胞一基質間との関連も重要であり, 近年, 細胞外マ トリックスとの接着についても追究が進められつつあ る. 細胞外マトリックスの構成成分であるラミニン 23 , フィブロネクチン ${ }^{24)}$, IV 型コラーゲン25), ビトロネクチ ン26)などの接着分子とこれらの分子に対するレセプター が同定され，レセプターは細胞と細胞外マトリックスの 接着に関与するだけでなく, 細胞生理機能にも関与する インテグリンファミリー ${ }^{27,28)}$ として取り扱われている. 癌細胞がこれらの接着分子と接着すると蛋白分解酵素の

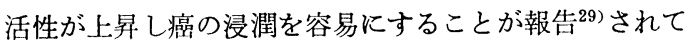
いる. また，これらの接着分子レセプターのモノクロー ナル抗体を利用し, 癌の転移・浸潤を抑制する試み ${ }^{30 \sim 34)}$ も進められている。したがって, 癌組織に拈ける転移・ 浸潤についての解明には, カドヘリン発現の動態ととも
にインテグリンファミリーについても検封を加えること が必要であろら.

癌組織に打ける E-カドヘリンの発現様式については Shiozaki ら ${ }^{9)}$ による食道癌の研究がある. 彼らは正常組 織と対比して癌組織に打ける発現様式を preserved type (非減弱型) と reduced type (減弱型) に大別し, 後者 をさらに不均一に発現するもの, 減弱するが均一に発現 するもの, 欠失するものの 3 つに分けている。 この分類 によれば，15例の食道扁平上皮癌のうち非減弱型は 4 例 にすぎず, 残りの症例の大部分は減弱かつ不均一に発現 するものであったという，また，血行性転移を伴った乳 癌の原発巣についても, すべてが減弱型の発現様式を示 したと報告している ${ }^{35)}$ 。これらのことから，本研究の浸 潤様式 4 型でみられた E-カドヘリンの発現減弱は, 細 胞間接着能の低下を示し, 癌細胞が容易に浸潤あるいは 転移しやすい状態にあることを示唆するものである.

しかし，E-カドヘリンを強く発現しているにもかかわ らず, 細胞間接着が弱く, 強い浸潤能をらかがわせる胃

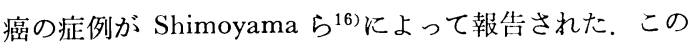
所見は, E-カドヘリンが局在していても接着機能が発揮 され得ないこともある可能性を示唆するものである. カ ドヘリン分子の構造をみると，その細胞内ドメインは $\alpha$-カテニンと複合体を形成して細胞骨格系と結合して いる ${ }^{36)}$. そしてカドへリンのもつ接着分子としての機能 は，この細胞質ドメインから制御を受けていることが最 近指摘されている ${ }^{37,38)}$. したがって，本研究においてみ られたよらな E-カドヘリンを強く発現している口腔原 発癌に打いても, 細胞質ドメインからの制御機構に何ら かの異常を生じ, 細胞接着機能が低下あるいは欠失して いる可能性が推察される。 これらのことから, E-カドへ リンの発現性と $\alpha$-カテニンの発現性の関連についてさ らに検討を要するものと考える。

\section{結語}

異なった臨床的進行度の口腔原発洏平上皮癌を対象に 細胞間接着分子 $\mathrm{E}$-カドヘリンの発現様式を検討した. その結果, E-カドヘリンの発現は，4 型の浸潤様式を示 す症例では減弱する傾向を示した。この所見は， E-カド ヘリン発現の減弱が癌の高浸潤能と密接に関連している ことを示唆している。

本研究に際し，扰ヒト $\mathrm{E}$ 一カドへリンモノクローナル

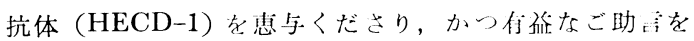
赐わりました京都大学: 竹市雅俊教授に深く感謝いたし ます。また適切なご助方とご援助を敗わり本した如路、 業大学: 阿形清和助教授に感谢いたします。

本論文の一部は第 46 回日本口腔科学会総会（1992伍。 4 月 18 日，名古屋）および第 34 回歯科基礎医学会釉会 
（1992年10月15日，岡川）に扣いて発表した。

\section{引用文 献}

1) Yoshida, C. and Takeichi, M.: Tetracarcinoma cell adhesion: Identification of a cellsurface protein involved in calcium-dependent cell aggregation. Cell 28: 217-224 1982.

2) Takeichi, M.: Cadherins: A molecular family essential for selective cell-cell adhesion and animal morphogenesis. Trends Genet 3: 2132171987.

3) Takeichi, M.: The cadherins: Cell-cell adhesion molecules controlling animal morphogenesis. Development 102: 639-655 1988.

4) Nose, A. and Takeichi, M.: A novel cadherin cell adhesion molecule: Its expression patterns associated with implantation and organogenesis of mouse embryos. J Cell Biol 103: 264926581986.

5) Hatta, K., Takagi, S., et al.: Spatial and temporal expression pattern of $\mathrm{N}$-cadherin cell adhesion molecules correlated with morphogenetic processes of chicken embryos. Dev Biol 120: 215-227 1987.

6) Hermanek, P. and Sobin, L.H.: TNM classification of malignant tumors. 4th. ed. Berlin: Spring-Verlag 1987, p 13-18.

7) Wahi, P.N., Cohen, B., et al.: International histological classification of tumours. No. 4. Histological typing of oral and oropharyngeal tumours. World Health Organization, Geneva, 1971, p 17-18.

8) Yamamoto, E., Kohama, G., et al.: Mode of invasion, Bleomycin sensitivity and clinical course in squamous cell carcinoma of the oral cavity. Cancer 51: 2175-2180 1983.

9) Shiozaki, H., Tahara, H., et al.: Expression of immunoreactive E-cadherin adhesion molecules in human cancers. Am J Pathol 139: 17-23 1991.

10) Owaribe, K., Nishizawa, Y., et al.: Isolation and characterization of hemidesmosomes from bovine corneal epithelial cells. Exp Cell Res 192: 622-630 1991.

11) Eidelman, S., Demsky, C.H., et al.: Expression of the cell-cell adhesion glycoprotein cell-CAM $120 / 80$ in normal human tissues and tumors. Am J Pathol 135: 101-110 1989.

12) Sakaki, T., Wato, M., et al.: Localization of E-cadherin adhesion molecules in human gingiva and gingival carcinoma. Acta Pathol Jpn 43: 99-106 1993.

13) Takeichi, M.: Cadherin cell adhesion receptors as a morphogenetic regulator. Science
251: 1451-1455 1991.

14) Schipper, J.H., Frixen, U.H., et al.: Ecadherin expression in squamous cell carcinoma of head and neck: Inverse correlation with tumor dedifferentiation and lymph node metastasis. Cancer Res 51: 6328-6337 1991.

15) Shimoyama, Y. and Hirohashi, S.: Cadherin intercellular adhesion molecule in hepatocellular carcinomas: Loss of E-cadherin expression in an undifferentiated carcinoma. Cancer Lett 57: 131-135 1991.

16) Shimoyama, Y. and Hirohashi, S.: Expression of E- and P-cadherin in gastric carcinomas. Cancer Res 51: 2185-2192 1991.

17) Behrens, J., Weidner, K.M., et al.: The role of E-cadherin and scatter factor in tumor invasion and cell motility. Experientia 59: 109-126 1991.

18）宋時澤, 森士朗, 他：扁平上皮癌のリンㅇ 節転移に関与する因子としての接着分子・浸潤 様式の比較検討(抄). 第11回日本口腔腫瘍学会 抄録集 83: 1993 .

19) Frixen, U.H., Behrens, J., et al.: E-cadherinmediated cell-cell adhesion prevents invasiveness of human carcinoma cells. J Cell Biol 113: 173-185 1991.

20) Vleminckx, K., Vakaet, L. Jr., et al.: Genetic manipulation of E-cadherin expression by epithelial tumor cells reveals an invasion suppressor role. Cell 66: 107-119 1991.

21) Mareel, M.M., Behrens, J., et al.: Downregulation of $\mathrm{E}$-cadherin expression in madin darby canine kidney (MDCK) cells inside tumors of nude mice. Int J Cancer 47: 9229281991.

22) Sakaki, T.: Tumor cell kinetics and expression of type IV collagen and E-cadherin in a human gingival carcinoma xenograft line in nude mice. J Osaka Dent Univ 26: 79-90 1992.

23) Liotta, L.A., Horan Hand, P., et al.: Monoclonal antibodies to the human laminin receptor recognize structurally distinct sites. Exp Cell Res 156: 117-126 1985.

24) Pytela, R., Pierschbacher, M.D., et al.: Identification and isolation of a $140 \mathrm{kd}$ cell surface glycoprotein with properties expected of a fibronectin receptor. Cell 40: 191-198 1985.

25) Kurkinen, M., Taylor, A., et al.: Cell surfaceassociated proteins which bind native type $\mathrm{IV}$ collagen or gelatin. J Biol Chem 259: 591559221984.

26) Pytela, R., Pierschbacher, M.D., et al.: A 125/115-kDa cell surface receptor specific for vitronectin interacts with the arginin-glycine- 
aspartic acid adhesion sequence derived from fibronectin. Proc Natl Acad Sci USA 82: 5766-5770 1985.

27) Tamkun, J.W., DeSiemone, D.W., et al.: Structure of integrin, a glycoprotein involved in the transmembrane linkage between fibronectin and actin. Cell 46: 271-282 1986.

28) Hynes, R.O.: Integrins: A family of cell surface receptors. Cell 48: 549-554 1987.

29) Matrisian, L.M.: Metalloproteinases and their inhibitors in matrix remodeling. Trend Genet 6: 121-125 1990.

30) Shearman, P.J., Gallatin, W.M., et al.: Detection of a cell-surface antigen correlated with organ-specific metastasis. Nature 286: 267-269 1980.

31) Vollmers, H.P. and Birchmeier, W.: Monoclonal antibodies that prevent adhesion of B16 melanoma cells and reduce metastases in mice: Crossreaction with human tumor cells. Proc Natl Acad Sci USA 80: 6863-6867 1983.

32) Vollmers, H.P. and Birchmeier, W.: Monoclonal antibodies inhibit the adhesion of mouse B16 melanoma cells in vitro and block lung metastasis in vivo. Proc Natl Acad Sci USA 80: 3729-3733 1983.
33) Vollmers, H.P., Imhof, B.A., et al.: Monoclonal antibodies NORM-1 and NORM-2 induce more normal behavior of tumor cells in vitro and reduce tumor growth in vivo. Cell 40: 547-557 1985.

34) Steinmann, C., Fenner, M., et al.: Invasive behavior of mouse sarcoma cells is inhibited by blocking a 37,000-dalton plasma membrane glycoprotein with Fab fragments. Proc Natl Acad Sci USA 81: 3747-3750 1984.

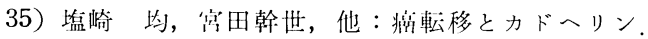
央験䋆: 10：1452-1456 1992 .

36) Ozawa, M., Baribault, H., et al.: The cytoplasmic domain of the cell adhesion molecule uvomorulin associates with three independent protein structurally related in different species. EMBO J 8: 1711-1717 1989.

37) Nagafuchi, A., Takeichi, M., et al.: The 102 kd cadherin-associated protein: Similarity to vinculin and posttranscriptional regulation of expression. Cell 65: 849-857 1991.

38) Ozawa, M., Ringwald, M., et al.: Uvomorulin-catenin complex formation is regulated by a specific domain in the cytoplasmic region of the cell adhesion molecule. Proc Natl Acad Sci USA 87: 4246-4250 1990. 